\title{
The Effect of Senam Sehat Indonesia Exercise on the Improvement of Lung Vital Capacity for Elderly in Universitas Majalengka
}

\author{
$1^{\text {st }}$ Indrayogi \\ Universitas Majalengka \\ Jl. Raya K H Abdul Halim No.103, \\ Majalengka Kulon, Kec. Majalengka, \\ Kabupaten Majalengka, Jawa Barat \\ 45418, Indonesia \\ indrayogi13@gmail.com
}

\author{
$2^{\text {nd }}$ M Nurhayati \\ Universitas Majalengka \\ Jl. Raya K H Abdul Halim No.103, \\ Majalengka Kulon, Kec. Majalengka, \\ Kabupaten Majalengka, Jawa Barat \\ 45418, Indonesia
}

\begin{abstract}
In developing of elderly in Higher Education, there are no activities to maintain physical condition. Through sports activities that are very potential to be carried out because of many elderly people in Universitas Majalengka. Besides doing physical activities in the form of exercises that can meet the oxygen requirements needed at work or exercise time, it is expected to be able to maintain and improve physical condition, because oxygen cannot be stored as supplies in the body, what can be done is to maintain and improve the ability of organs of the body that function to absorb and distribute oxygen so that it is always in good condition. This research method is a quasi-experimental method with the type of pre-test and the post-test group without control design. The population in the amount of 20 elderly people at Universitas Majalengka. The instrument used in this study was a modified Spirometer. This tool is used to measure lung vital capacity. Based on the results of the study it can be concluded that Senam Sehat Indonesia can affect and contribute significantly to the improvement of the vital lung capacity of the elderly.
\end{abstract}

Keywords-Senam sehat Indonesia, Lung Vital, Elderly, Universitas Majalengka

\section{INTRODUCTION}

Healthy life skills education is the habits that include physical health in the form of physical, mental health, and social. The existence of the motto "Mens sana in corpore sano" which is the motto of life of the Romans was impressed that a healthy body was considered a presupposition or Condisi Sine Quanom, which is in the form of "perfect human", related to two elements that in a healthy body there is a healthy soul too. [1]. Physical activity is considered as one out of the ten leading health indicators of public health. The physical and mental health benefits of physical activity, such as reducing the risk of developing heart disease, diabetes, colon cancer, high blood pressure, breast cancer, low back pain, and depression. (U.S. Department of Health and Human Services) [2]. It means that physical activity is considered as one of the ten main health indicators of public health. The physical and mental health benefits of physical activity, such as reducing the risk of heart disease, diabetes, colon cancer, high blood pressure, breast cancer, low back pain, and depression.

Inadequate physical activity and a sedentary lifestyle are important causes of many of the major diseases of developed societies, including coronary artery disease, stroke, hypertension, diabetes, obesity, osteoporosis, and arthritis. There has been an explosion of information over the past two decades on the health benefits of exercise. Besides, exercise and nutrition are closely linked, with each modifying the effects of the other. [3]. The point is that inadequate physical activity and inactive lifestyles are important causes of many of the major illnesses in advanced societies, including coronary artery disease, stroke, hypertension, diabetes, obesity, osteoporosis, and arthritis. There has been a lot of information over the past two decades about the health benefits of exercise. Also, exercise and nutrition are closely related, with each modifying the effect of the other.

Good fitness is the main asset for someone to do physical activities repeatedly in a relatively long time. It does not cause significant fatigue. Physical fitness is the body's ability to do physical work that is done every day without causing significant fatigue. A good physical condition is a person's main asset to do physical activity repeatedly in a relatively long time. It does not cause significant fatigue. Physical fitness is the body's ability to do physical work every day without

significant fatigue, [4] 
According to Kinsella and Taeuber in an increase in the number of elderly people in Indonesia is estimated at around $1990-2025$ by $414 \%$ [5]. This condition will place Indonesia at third rank with the largest elderly population in the world in 2022, after China and India. This can cause social problems, especially regarding health problems and the well-being of the elderly if not handled properly. The number of the elderly population (elderly) in Indonesia continues to grow. Until 2019, the elderly have reached 7 percent of the total population. This figure is expected to increase to 9.9 percent or 27 million people [6]. The Important thing for the elderly is body composition (body fat percentage). Age aging is usually accompanied by changes in body composition, decreased organ function, and metabolism. In the elderly group, there is generally a tendency to decrease physical activity resulting in imbalances that cause many problems and cause various health problems in the elderly [7].

The reviewed studies suggest that although motor performance tends to decline in old age, learning capabilities remain intact, and older adults can achieve considerable performance gains. The extent to which the learning capability varies with age, however, has to be considered very carefully. While most studies revealed that performance gains in fine motor tasks are diminished in older adults, results for gross-motor-skill learning are more contradictory. Additionally, there is considerable agreement on the finding that age-related learning differences are statistically more robust in complex tasks, whereas, in low-complexity tasks, the learning of younger and older adults is very similar. This applies to fine and gross motor skills. Relative age differences seem to become enlarged when effortful resources are required for motor performance. Thus, the decline in motor learning that accompanies aging is task-specific and not absolute. [8]

In the elderly coaching program in Higher Education, there are no activities to improve physical condition. Through sports activities that are very potential to be carried out because of many elderly people in Universitas Majalengka. Besides doing physical activities in the form of exercises that can sufficient the oxygen requirements needed at work or exercise time, it is expected to maintain and improve physical fitness, because oxygen cannot be stored as supplies in the body, so what can be done is to maintain and increase the ability of organs of the body that function to absorb and distribute oxygen so that it is always in good condition. This physical exercise is aerobic, in this case, one of the exercises suitable for old age is Senam Waitankung or in Indonesia known as Senam Sehat Indonesia [9]

Senam Sehat Indonesia is a gymnastics that utilizes oxygen through breathing to be oxidized in the body to achieve physical and spiritual health. Considering the length of the exercise, Senam Sehat Indonesia includes aerobic exercise which is a longer exercise time of 12 minutes. Senam Sehat Indonesia viewed from sports contain the elements of stretching exercises, exercises to increase joint flexibility, balance and coordination exercises that are beneficial to strengthen the function of the locomotor system, namely the joints of bones, muscles and peripheral nerves. It also increases heart and lung endurance but does not increase muscle explosive power, speed, and dexterity. [10]

\section{RESEARCH METHODS}

This is a quasi-experimental method with the type of pre-test and the post-test group without control design. 20 elderly of Universitas Majalengka participated as the sample of this research. Data collection methods in this study are pre-test and post-test group design consisting of pre-test, and post-test treatment. The purpose of the pretest is to obtain test data in the form of measurement of the Lung Vital Capacity of the elderly before treatment is held. In the treatment, Senam Sehat Indonesia Exercises were conducted 16 times plus 2 meetings for pre-test and post-test. Frequency of meetings 3 times each week. The purpose of the post-test is to obtain vital lung capacity data for the elderly after conducting Indonesian Healthy Gymnastics. Data analysis using the t-test formula. The Shortcut method formula is used in this study because it is more efficient to use. The testing criteria, if the $t_{\text {observed }}$ $>t_{\text {table }}$ it means that the Ho is rejected at a significance level of $5 \%$ with $\mathrm{dk}=\mathrm{n}-1$. Testing using this t-test can be continued if significantly distributed normally, which is tested using Kolmogorov Smirnov if a probability value of $>0.05$ is obtained. If not normally distributed, instead of the t-test in the form of the Wilcoxon test on nonparametric statistics.

\section{RESULT AND DISCUSSION}

The results of this study are the results of measurements of vital lung capacity in the elderly before and after participating in the Senam Sehat Indonesia training at Universitas Majalengka. Measurements were taken of 20 elderly people (aged over or equal to 55 years).

\begin{tabular}{|c|c|c|c|} 
TABLE I. AGE DISTRIBUTION OF RESPONDENTS \\
\hline No & Age & F & $\%$ \\
\hline 1 & $55-60$ & 8 & 36,67 \\
\hline 2 & $61-65$ & 5 & 26,67 \\
\hline 3 & $66-70$ & 5 & 26,67 \\
\hline 4 & $71-75$ & 2 & 10,00 \\
\hline & Amount & 20 & 100,00 \\
\hline
\end{tabular}

Based on the data obtained there are $36.67 \%$ of respondents aged between 55-60 years, $26.67 \%$ between 61-65 years, $26.67 \%$ between $66-70$ years, and $10 \%$ between $71-75$ years.

A. Lungs Vital Capacity Data Before Participating in Senam Sehat Indonesia Exercises

The average lung vital capacity measured before participating in the Senam Sehat Indonesia exercise can be seen in table II.

TABLE II. AVERAGE LUNG VITAL CAPACITY BEFORE ATTENDING THE SENAM SEHAT INDONESIA EXERCISE

\begin{tabular}{|c|c|}
\hline & $\begin{array}{c}\text { The vital capacity of the lungs } \\
\text { before participating in Senam } \\
\text { Sehat Indonesia }\end{array}$ \\
\hline
\end{tabular}




\begin{tabular}{|c|c|}
\hline Minimum Maximum & 500.00 \\
Mean Std. Deviation & 1500.00 \\
Variance & 946.0000 \\
& 259.2376 \\
$67204 / 138$ \\
\hline
\end{tabular}

The average vital lung capacity before participating in the Senam Sehat Indonesia exercise reached $946 \mathrm{ml}$ with a standard deviation of 259.2376. This shows that the vital lung capacity before participating in the Senam Sehat Indonesia exercises varies with the lowest vital lung capacity of $500 \mathrm{ml}$ and the highest $1500 \mathrm{ml}$.

B. The Activity of Senam Sehat Indonesia

The Senam Sehat Indonesia training activities at Universitas Majalengka were carried out from June to August 2020. Every week there were 3 exercises, in which each exercise went through three processes namely heating 15 minutes, core 30 minutes, and cooling in 17 minutes. The trainer consists of one person.

\section{Lungs Vital Capacity Data After Participating in Senam Sehat Indonesia Exercises.}

The average vital lung capacity measured after participating in the Senam Sehat Indonesia exercises can be seen in table III.
TABLE III. THE AVERAGE OF VITAL LUNG CAPACITY AFTER PARTICIPATING SENAM SEHAT INDONESIA EXERCISE

\begin{tabular}{|c|c|}
\hline & $\begin{array}{c}\text { The vital capacity of the lungs before } \\
\text { participating in Senam Sehat Indonesia }\end{array}$ \\
\hline Minimum Maximum Mean & 620.00 \\
Std. Deviation Variance & 1600.00 \\
& 1013.3333 \\
& 284.1240 \\
& 80726.437 \\
\hline
\end{tabular}

The average vital lung capacity after participating in the Senam Sehat Indonesia exercises reaches $1013.33 \mathrm{ml}$ with a standard deviation of 284.1240. It can be seen from the tables and graphs that the lung's vital capacity after participating in the Senam Sehat Indonesia exercise also varies with the lowest vital lung capacity of $620 \mathrm{ml}$ and the highest $1600 \mathrm{ml}$.

\section{Test of Normality}

A normality test is used to determine whether the data obtained is normally distributed or not. In testing it can be seen from Kolmogorov Smirnov, if a Lo value of significance $<0.01$ is obtained, it can be concluded that the data are not normally distributed. Kolmogorov Smirnov test results can be seen from the SPSS output in the following table.

\begin{tabular}{|c|c|c|c|c|c|c|}
\hline & \multicolumn{3}{|c|}{ Kolmogorov-Smirnov $^{a}$} & \multicolumn{3}{|c|}{ Shapiro-Wilk } \\
\hline & Statistic & $d f$ & Sig. & Statistic & $d f$ & Sig. \\
\hline $\begin{array}{l}\text { Kapasitas vital paru sebelum } \\
\text { mengikuti senam sehat Indonesia }\end{array}$ & .147 & 20 & .098 & .965 & 20 & .470 \\
\hline $\begin{array}{c}\text { Kapasitas vital paru setelah } \\
\text { mengikuti senam sehat Indonesia }\end{array}$ & .162 & 20 & .042 & .923 & 20 & .043 \\
\hline
\end{tabular}

The table above obtained significance value for vital lung capacity before participating in the Senam Sehat Indonesia training at 0.098 and after participating in Senam Sehat Indonesia training at 0.042. Both the significance value of the test $>0.01$, it can be concluded that the data are normally distributed. So to test the next hypothesis used parametric statistics, namely the t-test.

\section{E. Lung Vital Capacity Test After Participating in The Senam Sehat Indonesia Activities}

To find out the increase in lung vital capacity after participating in the Senam Sehat Indonesia exercises can be seen from the t-test as in the following table.

TABLE V. LUNG CAPACITY3TEST AFTER PARTICIPATING IN THE SENAM SEHAT INDONESIA

\begin{tabular}{|c|c|c|c|c|c|}
\hline LungVitalCapacity & Average & Significant & $\mathrm{T}_{\text {observed }}$ & $\mathrm{T}_{\text {table }}$ & Note \\
\hline Before & 946.00 & \multirow{2}{*}{$7.12 \%$} & 3.68 & 2.46 & Ho rejected \\
\hline After & 1013.33 & & &
\end{tabular}

Note:

Ho: $\mu_{1} \geq \mu_{2}$ (no significant) Ho : $\mu_{1}<\mu_{2}$ (there is a significant)

Based on the results of the t-test above $t_{\text {observed }}$ is 3,68 > $\mathrm{t}_{\text {table }}$ is $(2,46)$ at the significant 0,01 it can be concluded that $\mathrm{Ho}$ is rejected, whereas $\mathrm{Ha}$ is with an increase of $7.12 \%$.

Based on the results of the study showed that there was a significant increase in lung vital capacity of the elderly after participating in the Senam Sehat Indonesia at Universitas Majalengka. An increase in vital lung capacity in the elderly is caused by physiological responses to the body, namely the thickening of the diaphragm muscles which results in the process of respiration can be done optimally. Senam Sehat Indonesia uses diaphragmatic breathing exercises.

According to Nakamura in the ([10]), breathing with the diaphragm causes more $\mathrm{O} 2$ volume to enter the lungs so that the heart can pump more blood. It is this breathing exercise that makes a real contribution to increasing the vital lung capacity for the elderly at Majalengka University. In the Senam Sehat Indonesia, there are elements of exercise that are stretching exercises, exercises to increase joint flexibility, balance, and coordination exercises that are useful for strengthening the function of the locomotor system namely the joints of bones, muscles and peripheral nerves. In other components of physical fitness, SSI helps increase heart and lung endurance but does not increase muscle power, speed, and agility. [10] 


\section{CONCLUSION}

Based on the results of the study it can be concluded that the Senam Sehat Indonesia can affect the increase in the vital lung capacity of the elderly. Senam Sehat Indonesia Exercise contributes significantly to increasing vital lung capacity in the elderly, which is equal to $7.12 \%$. Based on the conclusions, it can be suggested that the elderly at the Universitas Majalengka be more motivated to do the Senam Sehat Indonesia activities as a form of training to promote excellent physical conditions in maintaining physical levels

\section{REFERENCES}

[1] Indrayogi, "KORELASI ANTARA TINGKAT KESEGARAN JASMANI (PHYSICAL FITNESS) DAN KESEHATAN MENTAL (MENTAL HYGIENE) DENGAN PRESTASI BELAJARPENDIDIKAN JASMANI SISWA SEKOLAH DASAR," J. RESPECS, vol. 2, no. 1, 2020.

[2] S. Y. Cheung, "Gymnastics for all in Hong Kong," Int. J. Phys. Educ. Sport. Heal., vol. 7, no. 4, pp. 11-15, 2020.

[3] A. I. Oluwasegun, "Physical activity, nutrition and health: An antidote to overall wellbeing," Sleep, p. 8, 2013.

[4] O. Oktariyana, M. Asmawi, and I. S. Zamzami, "Enhancement of Students' Fitness Using Rhythmic Gymnastics (Batara Gymnastics)," Act. J. Phys. Educ. Sport. Heal. Recreat., vol. 9, no. 1, pp. 23-27, 2020

[5] Darmojo and Martono, Geriatri. Jakarta: Balai Penerbit FKUI, 2004.

[6] N. N. Nibras, "Hanya 13,2 Persen Lansia Di Indonesia Yang Sehat.," 2019. https://sains.kompas.com/read/2019/07/05/120500723/.

[7] Beltasar and Novi, "Pengaruh Latihan Senam Tai Chi dan Wai Tan Kung terhadap Daya Tahan Jantung Paru dan Komposisi Tubuh (Persentase Lemak Tubuh Pada Lanjut Usia)," Universitas Padjadjaran, 2010.

[8] C. Voelcker-Rehage, "Motor-skill learning in older adults-a review of studies on age-related differences," Eur. Rev. Aging Phys. Act., vol. 5, no. 1, pp. 5-16, 2008.

[9] BKKBN, Materi Penyuluhan Bina Keluarga Lansia. 1996.

[10] Baranas, Senam Sehat Indonesia. Yogyakarta, 1989. 